\title{
Faz Değiştiren Madde Olarak n-Hekzadekan Esaslı Mikrokapsüllerin Hazırlanması, Karakterizasyonu ve Isıl Performansının T-Kayıt Yöntemiyle Belirlenmesi
}

\author{
Hatice Hande Mert ${ }^{1 *}$, Mehmet Selçuk Mert ${ }^{2}$ \\ ${ }^{1}$ Yalova Üniversitesi, Mühendislik Fakültesi, Kimya ve Süreç Mühendisliği Bölümü, Yalova, Türkiye, (ORCID:0000-0003-0743-1981) \\ ${ }^{2}$ Yalova Üniversitesi, Mühendislik Fakültesi, Enerji Sistemleri Mühendisliği Bölümü, Yalova, Türkiye, (ORCID: 0000-0002-8646-0133)
}

(İlk Geliş Tarihi 14 Ocak 2020 ve Kabul Tarihi 22 Şubat 2020)

(DOI: 10.31590/ejosat.674613)

\begin{abstract}
ATIF/REFERENCE: Mert, H.H., \& Mert, M.S. (2020). Faz Değiştiren Madde Olarak N-Hekzadekan Esaslı Mikrokapsüllerinin Hazırlanması, Karakterizasyonu ve Isıl Performansının T-Kayıt Yöntemiyle Belirlenmesi. Avrupa Bilim ve Teknoloji Dergisi, (18), $148-161$.
\end{abstract}

$\ddot{\mathbf{O} z}$

Faz değiştiren maddeler (FDM'ler), 1sıl enerjinin gizli 1sı olarak depolanabilmesine olanak sağlayan, sıvıdan katıya ya da katıdan sıvıya faz değişimi esnasında büyük miktarda ısının depolanmasına veya salınmasına izin veren yeni nesil enerji depolama malzemeleridir. FDM'lerin faz değişimi esnasında belirli bir hacimde tutmak amacıyla makro veya mikro/nano ölçekte kapsüllenmeleri gerekmektedir. Kapsülleme işlemi sayesinde malzemenin dış çevrelerden etkilenme derecesi azaltıllığg gibi malzemenin katıdan sıvıya geçişi esnasında mevcut kabuk hacminde sabit tutulması mümkün olmakta ve 1sı transfer yüzeyi de arttırılmaktadır. Bu çalışmada, organik FDM'ler sınıfında yer alan bir parafin olan ve binalarda iç ortamın ısıl konforunun sağlanması hususunda uygun faz değişim sıcaklık aralığı sayesinde 1Sı depolama malzemesi olarak kullanım potansiyeli bulunan n-hekzadekan (n-HD), faz inversiyon emülsifikasyonu yöntemiyle mikro boyutta kapsüllenmiş̧tir. Faz dönüşümü esnasında sızdırma problemi nedeniyle doğrudan uygulamalarda kullanımı uygun olmayan n-hekzadekanın kapsülleme işleminde, kabuk olarak binalarda yalıtım amaçlı sıklıkla kullanılan stiren (St) ve çapraz bağlayıcı divinilbenzen (DVB) kullanılmıştır. Elde edilen mikrokapsüllerin ısıl özellikleri diferansiyel taramalı kalorimetre (DSC) ve Termogravimetrik Analiz (TGA) ile incelenirken, morfolojik özellikleri ve kimyasal yapısı ise sırasıyla Taramalı Elektron Mikroskobu (SEM) ve Fourier Dönüşümlü Kızılötesi (FT-IR) spektroskopisi ile belirlenmiştir. Elde edilen mikrokapsüllerin erime entalpisi 131,074 J/g olarak bulunurken, FDM içeriği \%68,55 olarak hesaplanmıștır. Mikrokapsüllenmiş FDM'nin (MikroFDM) ve saf n-hekzadekanın 1sı depolama özellikleri sıcaklık kontrollü sirkülasyonlu bir banyo sisteminde karşılaştırmalı olarak test edilmiştir. T-Kayıt yöntemiyle gerçekleştirilen ölçümlerde elde edilen 1sıl özellikler DSC analizinden elde edilen sonuçlarla karşılaştırmalı olarak sunulmuştur. N-hekzadekan faz değişim maddesini içeren mikrokapsüllerin sahip oldukları boyut aralığı, faz değişim sıcaklık aralığı, 1sı depolama kapasitesi ve gösterdikleri 1sıl performans açısından binalarda iç mekan uygulamalarında ısıl konforun sağlanması noktasında kullanımının uygun olduğu ve binalarda enerji tasarrufu açısından önemli kazanımlar sağlayabilecekleri öngörülmüştür.

\section{Preparation, Characterization of n-Hexadecane-based Microcapsules as a Phase Change Material and Determination of ItsThermal Performance via T-History Method}

\footnotetext{
* Sorumlu Yazar: Yalova Üniversitesi, Mühendislik Fakültesi, Kimya ve Süreç Mühendisliği Bölümü, Yalova, Türkiye, ORCID:0000-0003-07431981, hndmert@yalova.edu.tr
} 
European Journal of Science and Technology

\begin{abstract}
Phase change materials (PCMs) are new generation energy storage materials that allow the storage of thermal energy as latent heat, allowing the storage or release of large amounts of heat during the phase change from liquid to solid or solid to liquid. PCMs have to be encapsulated on a macro or micro / nano scale to maintain a certain volume during phase change. By means of the encapsulation process, the degree to which the material is affected from external environments is reduced and it is possible to keep the material constant volume during the phase change process of the material from solid to liquid and the heat transfer surface is increased. In this study, n-hexadecane (n-HD), which is a paraffin which is in the class of organic PCMs and which has the potential to be used as heat storage material with the appropriate phase change temperature range in order to provide the thermal comfort of the indoor environment in buildings, is encapsulated in micro-dimension by phase inversion emulsification method. Styrene (St) and cross-linker divinylbenzene (DVB), commonly used for insulation purposes in buildings, were used as the shell in the encapsulation process of $\mathrm{n}$ hexadecane, which is not suitable for direct applications due to leakage problems during phase change process. The thermal properties of the obtained microcapsules were investigated by Differential Scanning Calorimetry (DSC) and Thermogravimetric Analysis (TGA) whereas morphological properties and chemical structure of them were determined by Scanning Electron Microscopy (SEM) and Fourier Transform Infrared Spectroscopy (FT-IR), respectively. The melting enthalpy of the obtained microcapsules was 131,074 J / $\mathrm{g}$, while the PCM content was calculated as $68.55 \%$. The heat storage properties of microencapsulated PCM (MicroPCM) and pure nhexadecane were comparatively tested in a temperature controlled circulation bath system. The thermal properties obtained in the measurements performed by T-History method are presented in comparison with the results obtained from DSC analysis. It is envisaged that microcapsules containing $n$-hexadecane phase change material are suitable for use in indoor applications in buildings in terms of particle size range, phase change temperature range, heat storage capacity and thermal performance and they can provide significant gains in terms of energy savings in buildings.
\end{abstract}

Keywords: Phase Change Material, Microencapsulation, Thermal Energy Storage, T-History Method.

\title{
1. Giriș
}

Enerji bir çok proses için anahtar bileşendir. Artan nüfus, gelişen teknoloji ve sanayileşme, enerjiye olan talebi her geçen gün artırmakta, bu durum da enerjinin verimli ve tasarruflu kullanılmasını gerekli kılmaktadır. Son yıllarda, enerjinin verimli ve tasarruflu kullanılması amacıyla enerji depolama teknolojileri üzerine bilim insanları tarafindan birçok çalışma yapılmıştır. Bu teknolojilerden biri olan gizli 1sı depolama son zamanlarda dikkat çeken ve umut vadeden bir enerji depolama yöntemidir. Faz değişim maddesi (FDM) adı verilen enerji malzemeleri kullanılarak, enerji gizli 1s1 formunda depolanabilir. FDM'ler uygulanacakları sistemin özelliklerine ve çalışma aralıklarına uygun olarak çok çeşitli yapılarda ve formlarda tasarlanıp üretilebilirler (Mert ve ark., 2018; Mert ve ark.,2019a; Mert ve ark., 2019b; Sarı ve ark., 2012; Karaipekli ve ark., 2016). Bununla birlikte, FDM özelliği gösteren maddeler, doğrudan kullanılabildikleri gibi farklı malzemeler ile karıştırılarak veya mikro/makro boyutlarda kapsüllenerek kullanılabilirler. Faz değişim maddesi olarak kullanılan malzemelerin arasında bulunan ve bir tür parafin olan n-hekzadekan, bugüne kadar pek çok çalışmada incelenmiştir. Bo vd., soğutma sistemlerinde kullanılmak üzere tetradekan, hekzadekan ve bunların ikili karışımlarının ısıl özelliklerini araştırmış ve soğuk depolama sistemi için kullanılma potansiyelini göstermiştir (Bo ve ark., 1999). Bo vd. bir başka çalışmalarında ise teorik hesaplamalar sonucunda tetradekan-hekzadekan ikili sisteminin sıcaklık-bileşim faz diyagramını elde etmişlerdir (Bo ve ark., 2003). Sarıer ve Önder, yüksek 1sı depolama kapasitesine sahip parafinler olan n-hekzadekan ve n-oktadekan faz değişim maddelerini farklı oranlarda poliüretan köpük içine entegre ederek ısıl yalıtım için tasarlanan ürünün sıcaklık değişimlerine karşı tampon etkisindeki iyileşmeyi araştırmışlardır (Sarıer ve ark., 2007). Alay vd., ısı depolama özelliğine sahip tekstil ürünlerinin üretiminde kullanılmak amacıyla n-hekzadekan faz değişim maddesini emülsiyon polimerizasyonu ile üç farklı çapraz bağlayıcı (Allilmetakrilat, Etilen glikol dimetakrilat ve Glisidil metakrilat) varlığında poli(etil akrilat) kabuk ile kapsüllemişler ve üretilen mikrokapsülleri karakterize etmişlerdir (Alay ve ark., 2009). Etilen glikol dimetakrilat ve glisidil metakrilat kullanılarak hazırlanan mikrokapsüllerin sahip oldukları 1sı depolama kapasiteleriyle tekstil ürünlerinde kullanımının uygun olduğu sonucunu rapor etmişlerdir. Fang ve arkadaşları, 1sıl enerji depolama sistemleri için sol-jel yöntemiyle alev geciktirici özelliği olan nhekzadekan/silisyum dioksit kompozit malzemeleri hazırlamışlar ve kompozitlerin alev geçiktirici özelliğini daha da arttırmak için kompozitlere genişletilmiş grafit eklemişlerdir (Fang ve ark., 2010). Gao vd. ise n-hekzadekanı poliüre-melamin formaldehit reçine ile kapsüllemişler ve sadece poliüre kabukla kapsüllemeye kıyasla mikrokapsüllerin termal kararlılığının arttığını ortaya koymuşlardır (Gao ve ark., 2010). Jeon vd. bir başka çalışmada binalarda zemin ısıtmada kullanılmak üzere eksfoliye grafit nanotabakaları içeren kompozit faz değişim maddeleri hazırlamışlar ve isıl iletkenliği arttırmayı hedeflemişlerdir (Jeon ve ark., 2012). Oktadekan, hekzadekan ve parafinden oluşan üç farklı faz değişim maddesine $\% 3$ ve $\% 5$ oranlarında eksfoliye grafit nanodolguları ilave etmişler ve isıl iletkenlikteki en büyük artışın oktadekan temelli kompozit de görüldügünü rapor etmişlerdir. Literartürde bir destek malzemesine faz değişim maddesinin emdirilmesiyle hazırlanan şekil kararlı faz değişim maddeleri de bulunmaktadır. Kim ve arkadaşları, faz değişim maddesi olarak hekzadekanı vakum sisteminde gözenekli bir malzeme olan eksfoliye grafite emdirmek suretiyle kompozit malzeme hazırlamışlar ve hazırladıkları malzemeyi bina harcına ekleyerek bunun ısıl performansını 1sıtmasoğutma testleriyle analiz etmişlerdir (Kim ve ark., 2014). Velez vd., lineer alkanlar olan n-hekzadekan (C16), n-heptadekan (C18) ve n-eikosanın (C20) 1sıl özelliklerini (termal iletkenlik ve termal difüzivite) incelemişler ve sonuçları literatürle karşılaştırmışlardır (Velez ve ark., 2015). Sarıer ve arkadaşları n-hekzadekan içeren bir başka çalışmalarında n-hekzadekan ve n-oktadekanı ayrı ayrı poli(üre-formaldehid) kabuk ile gümüş nanopartiküller varlığında kapsüllemişler ve özellikle tekstil uygulamalarında kullanım potansiyeli olduğunu bildirmişlerdir (Sarıer ve ark., 2015). Literatürde faz değişim maddelerinin kapsülasyonu için biyokütle kaynaklarının kullanıldığı çalışmalar da bulunmaktadır. Gondora ve arkadaşları, biyoyakıt üretiminde yan ürün olarak çıkan ve karbon temelli bir ürün olan pirinç kabuğu külünü n-hekzadekanı kapsüllemek için kullanmışlar ve bu çalışma ile biyokütle kökenli olan karbon temelli malzemelerin 1 sıl enerjinin geri kazanımı ve depolanması uygulamalarında kullanım potansiyelini ortaya koymuşlardır (Gondora ve ark. 2016). Lashgari ve arkadaşları ise kapsülasyon verimi ve mikrokapsüllerin ısıl performansına kabuk malzemenin 
esnekliğinin etkisini ortaya koymak amacıyla, n-hekzadekanı süspansiyon polimerizasyonuyla polimetil metakrilat (PMMA) ve poli(bütil akrilat-ko-metil metakrilat) (poli(BA-ko-MMA)) kabuklarla kapsüle etmişlerdir. Çalışma sonucunda elde edilen bulgulara göre, 1sıl enerji depolama özelliği ve kabuk esnekliği açısından ağırlıkça \%25'den az miktarda bütil akrilat içeren poli(bütil akrilat-kometil metakrilat) kabuğun istenilen performansı ortaya koyduğunu rapor edilmiştir (Lashgari ve ark., 2017).

$\mathrm{Bu}$ çalışmada, organik FDM'ler sınıfında yer alan bir parafin olan n-hekzadekan, literatürden farklı olarak faz inversiyon emülsifikasyonu yöntemiyle ve stiren-divinilbenzen çapraz bağlı polimer kabuk içerisine mikro boyutta kapsüllenmiştir. Elde edilen bulgular temelinde, n-HD-St-DVB MikroFDM'in sahip olduğu 1sıl enerji depolama kapasitesi, faz değişim sıcaklık aralığı, 1sıl kararlılığı, kapsül boyutları ve çekirdek-kabuk malzeme uyumu araştırılmıştır. Bununla birlikte, elde edilen mikro yapıdaki FDM'nin performansının belirlenmesinde geleneksel yöntemlerin yanısıra T-Kayıt yöntemi kullanılmıştır. Bunun için, saf FDM ve MikroFDM'in ısıl performansları sıcaklık kontrollü sirkülasyonlu bir su banyosu sisteminde, deneysel ve sayısal yöntemin birlikte kullanıldığı T-kayıt yöntemi temelinde test edilmiştir. Elde edilen sonuçlar, DSC analizinden elde edilen 1sıl özellikler ile karşılaştırmalı olarak sunulmuştur.

\section{Materyal ve Metot}

\subsection{Materyaller}

Stiren (St) (monomer, Merck, Darmstadt, Almanya), divinilbenzen (DVB) (çapraz bağlayıı, \% \%0, Aldrich Chemistry, Steinheim, Almanya), Setil trimetil amonyum bromür (CTAB) (katyonik surfaktan, \%98 Sigma) ve n-hekzadekan (HD) (parafin, Merck, Darmstadt, Almanya) herhangi bir saflaştırma işlemi yapılmadan kullanılmıştır. 2,2'-azobisizobütironitril (AIBN) (başlatıcı, \%98, Aldrich Kimya, Steinheim, Almanya) etanolden tekrar kristallendirme işlemi yapılarak kullanılmıştır. Yapılan tüm deneylerde deiyonize su kullanılmıştır.

\subsection{Deneysel Yöntem}

\subsubsection{Mikrokapsüllenmiş FDM'nin Hazırlanması}

HD/St-DVB mikrokapsülleri aşağıda verilen prosedüre göre (Şekil 1) faz inversiyon emülsifikasyonu yöntemiyle hazırlanmıştır. Mikrokapsüllerin bileşimi Tablo 1'de yer almaktadır. Kapsülasyon işlemi çekirdek/kabuk oranı hacimce 1:1 olacak şekilde gerçekleştirilmiştir. Mikrokapsüllerin çekirdek kısmı HD faz değişim maddesinden oluşurken, kabuk malzeme St-DVB kopolimerlerinden oluşmuştur. St ve DVB monomerleri, HD parafini ve AIBN başlatıcısının (0,1 g) oda sıcaklığında karıştırılmasılyla oluşturulan yă̆ fazına, CTAB içeren su fazının $(50 \mathrm{mmol} / \mathrm{L})$ damlatma hunisi yardımıyla damla damla eklenmesiyle hazırlanan emülsiyon, mekanik karıştırıcı ile oda sıcaklığında 1 saat karıştırılmıştır. Hazırlanan emülsiyon geri soğutucu bağlı üç boyunlu cam bir reaktöre aktarılmış ve $70^{\circ} \mathrm{C}$ deki yağ banyosunda 6 saat süreyle polimerleşme reaksiyonu gerçekleştirilmiştir. Reaksiyon sonunda elde edilen ürün oda sıcaklığına soğutularak, etanolde çöktürülmüştür. Süzme ve yıkama işlemlerinin ardından elde edilen mikrokapsüller, $40^{\circ} \mathrm{C}$ 'deki vakum etüvünde 24 saat süreyle kurutulmuştur.

Tablo 1. Mikrokapsüllenmiş FDM'nin kimyasal bileşimi

\begin{tabular}{|c|c|c|}
\hline $\begin{array}{c}\text { Mikrokapsüllenmiş } \\
\text { FDM }\end{array}$ & Kimyasal & $\begin{array}{c}\text { Hacim Yüzdesi } \\
(\mathbf{\%} \text { v/v) }\end{array}$ \\
\hline Çekirdek Malzeme & HD & 50 \\
\hline \multirow{2}{*}{ Kabuk Malzeme } & St & 45 \\
\cline { 2 - 3 } & DVB & 5 \\
\hline
\end{tabular}




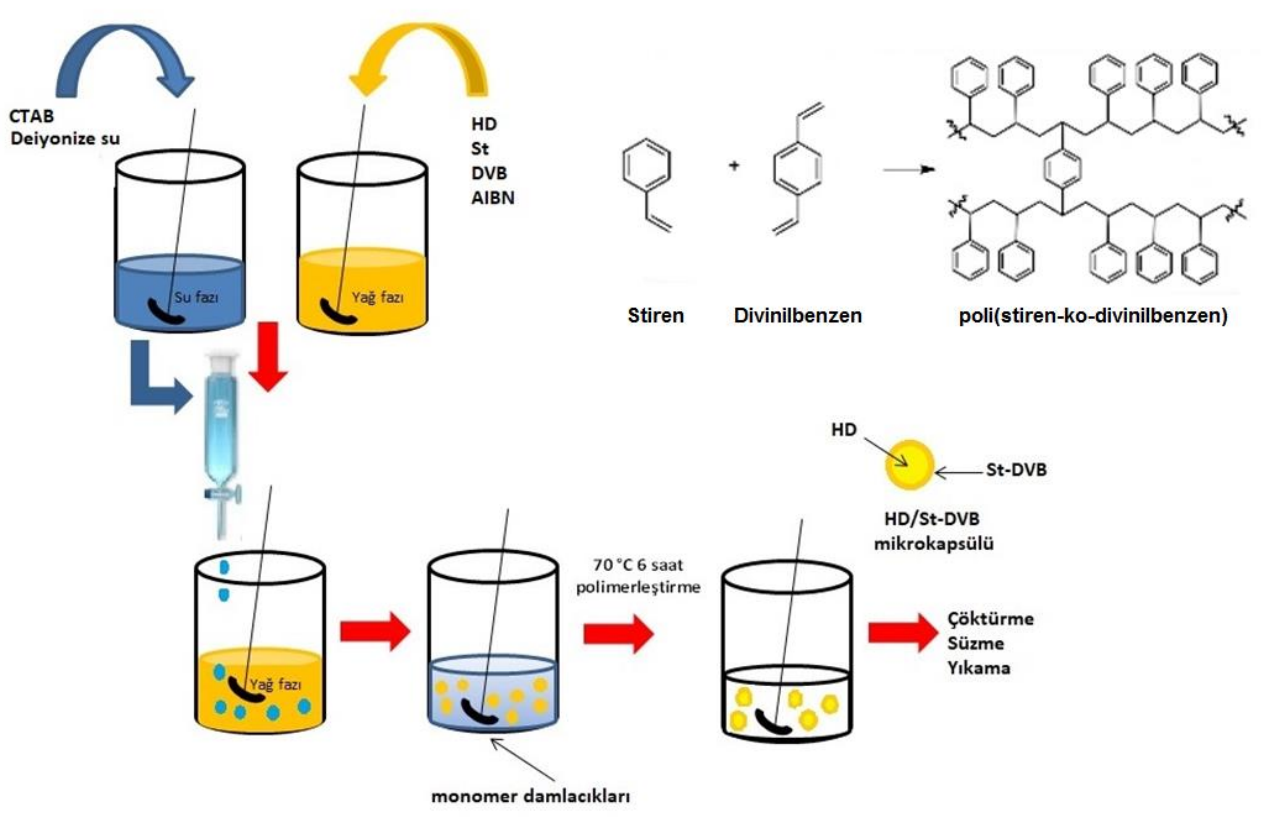

Şekil 1. Mikrokapsüllerin Hazırlanması

\subsubsection{Mikrokapsüllenmiş FDM'nin Karakterizasyonu}

HD/St-DVB mikrokapsüllerinin ve boş kabuk malzeme St-DVB kopolimerinin morfolojik özellikleri Taramalı Elektron Mikroskobu (SEM) (FEI Inc. Inspect S50 SEM-EDAX) kullanılarak belirlenmiştir. Mikrokapsüllerin partikül boyut dağıllımı, SEM görüntüleri kullanılarak CoralDRAW X8 programı ile elde edilen partikül boyut ölçüm verilerinin histogramları oluşturularak bulunmuştur. Mikrokapsüllenmiş FDM'nin, saf n-hekzadekanın ve St-DVB boş kabuk malzemenin kimyasal yapılarının saptanması amacıyla, Perkin Elmer Spectrum 100 FT-IR spektrofotometresi kullanılarak oda sicaklı̆̆ında $650-4000 \mathrm{~cm}^{-1}$ dalga boyu aralığında FT-IR spektrumları elde edilmiştir. Elde edilen malzemelerin 1sıl özellikleri termal analiz cihazı (Seiko TG / DTA 6300,Seiko Instruments, Tokyo, Japan) yardımıyla $0-600^{\circ} \mathrm{C}$ sıcaklık aralığında, $10{ }^{\circ} \mathrm{C}_{\mathrm{dk}}{ }^{-1} 1$ sıtma hızında ve azot (N2) atmosferi altında belirlenmiş̧tir. Saf n-hekzadekanın, boş kabuk malzemenin ve mikrokapsüllenmiş FDM'nin 1sıl enerji depolama kapasiteleri (erime entalpisi, $\Delta \mathrm{H}_{\mathrm{e}}$ ve kristallenme entalpisi, $\Delta \mathrm{H}_{\mathrm{k}}$ ) ve faz değişim sıcaklıkları (erime sıcaklığı, $\mathrm{T}_{\mathrm{e}}$ ve kristallenme sıcaklığı, $\mathrm{T}_{\mathrm{k}}$ ) ise Diferansiyel Taramalı Kalorimetre (DSC) cihazı (DSC $7020 \mathrm{HITACHI)} \mathrm{ile}-20$ ila $80^{\circ} \mathrm{C}$ sıcaklık aralığında, $10^{\circ} \mathrm{C} . \mathrm{dk}^{-1}$ 1sıtma/soğutma hızında ve azot $\left(\mathrm{N}_{2}\right)$ atmosferi altında ölçülmüştür. N-hekzadekanın kapsüllenme oranı diğer bir ifadeyle FDM içeriği (\%) ise ölçülen entalpi değerlerinden aşağıdaki formüle göre hesaplanmıştır:

Mikrokapsüllenmiş FDM $(\%)=\left[\Delta \mathrm{H}_{\text {mikroFDM }} / \Delta \mathrm{H}_{\mathrm{FDM}}\right] \times 100$

Burada $\Delta \mathrm{H}_{\text {mikroFDM }}$ mikrokapsüllenmiş faz değiştiren maddenin erime entalpisini gösterirken, $\Delta \mathrm{H}_{\mathrm{FDM}}$ kapsülenmemiş faz değiştiren maddenin erime entalpisini ifade etmektedir.

\subsubsection{Isı Depolama Kapasitesinin Sıcaklık-Kayıt (T-History) Yöntemiyle Belirlenmesi}

Sicaklık-Kayı (T-Kayıt) Yöntemi (Temperature-History (T-History)) ilk olarak Yinping ve ark. tarafından 1999 yllında önerilmiş ve kullanılmıştır (Yinping ve ark., 1999). Bu yöntem ile analiz edilen maddenin, erime-donma sıcaklıkları, erime gizli 1sısı, 1sıl iletkenliği ve özgül ısısı deneysel ve sayısal yöntem birlikte kullanılarak tayin edilebilmektedir. T-Kayıt yöntemi temelde özellikleri bilinen bir referans madde kullanılarak başka bir maddenin 1 sıl özelliklerinin belirlenmesi prensibine dayanmaktadır. T-Kayıt ile 1sıl özellikleri belirlemek için iki adet test tüpüne ihtiyaç vardır. Bu tüplerden bir tanesine analizde kullanılacak referans madde konur. Genellikle, referans madde olarak özellikleri iyi bilinen saf su tercih edilmektedir. Diğer tüp ise, 1sıl özellikleri belirlenmek istenen madde ile doldurulur. T-Kayıt'ın ilk önerildiği çalışmada (Yinping ve ark., 1999) tüpler, maddenin erime sıcaklığının üzerindeki bir sıcaklıkta bulunan bir su banyosuna batırılmış ve tüplerin banyo ile 1sıl dengeye gelmesi beklenilmiştir. Daha sonra, tüpler aniden banyodan çıarılarak atmosferik koşullara maruz bırakılmış ve tüp sıcaklıklarının zamanla değişimi ısıl-çift (thermocuple) ve veri kayıt cihazı (data logger) kullanılarak kayıt edilmiştir. Sonuçta, elde edilen veriler kullanılarak sayısal yöntem ile istenilen özellikler hesaplanmıştır. Bugüne kadar, T-Kayıt yöntemi pek çok çalışmada kullanılmıştır (Lasggari ve ark., 2017; Yinping ve ark., 1999; Hong ve ark., 2004; Peck ve ark., 2006). Bu çalışmalar incelendiğinde, temel prensibi aynı olmak birlikte küçük farklılıklarla başka şekillerde de uygulanabildiğine rastlamak mümkündür. 
T-Kayıt yönteminde araştıılan maddenin soğuma eğrisi ve sayısal yöntem kullanılarak hesap yapılabilmekte ve bazı özellikler bu şekilde tespit edilebilmektedir. Aşırı soğuma (subcooling) özelliği olan bir maddenin tipik T-Kayıt eğrisi Şekil 2a'da, genellikle referans madde olarak kullanılan saf suyun soğuma eğrisi Şekil $2 b$ 'de ve hesaplamalarda kullanılan dönüm noktasını (katılaşma sonunu) gösteren birinci türev Şekil 2c'de gösterilmiştir. Şekil 2a'ya göre madde erime noktasının altına soğutulmasına rağmen katılaşma işlemi hemen başlamamaktadır. Bu olay, aşırı soğuma (supercooling) veya bazen aşırı ergime (supercooling) olarak da adlandırılmaktadır ki katılaşma sürecini tetikleyen ve başlatan bu aşırı soğuma prosesidir. Katılaşmanın başlamasıyla birlikte faz değişimi gösteren maddenin sıcaklığı bir miktar yükselmekte ve bir noktadan sonra sıcaklığın tekrar düşmesiyle beraber tamamen katı faz elde edilmektedir.

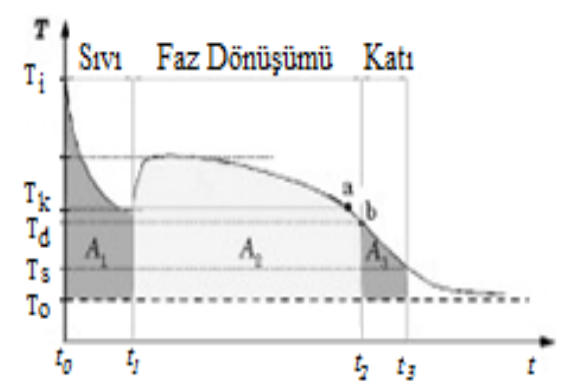

(a) FDM

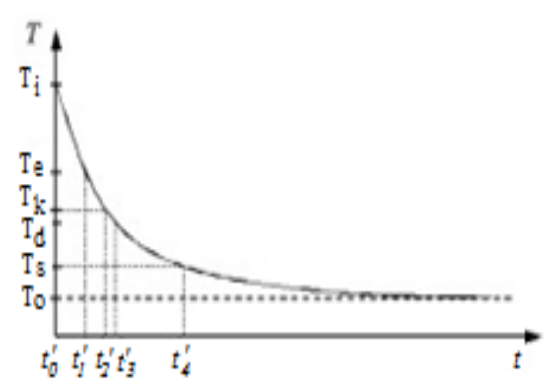

(b) Saf su

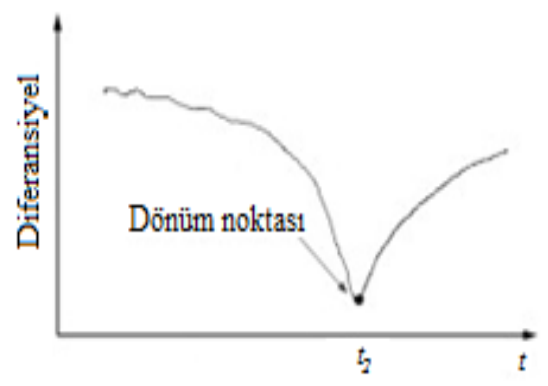

(c) Birinci türev

Şekil 2. (a) Aşırı soğuma özelliği olan bir maddenin tipik T-Kaylt soğuma ĕgrisi (b) Referans madde olarak saf suyun soğutma sirasindaki tipik T- Kayıt eğrisi (c) dönüm noktasının (katılaşma sonu) birinci türevine ait eğri (Hong ve ark., 2004)

Aşırı soğuma özelliği olan bir maddenin tipik T-Kayıt soğuma eğrisi kullanılarak ve sıvı fazdan katı faza olan değişim süreci dikkate alınarak enerji denklemleri matematiksel olarak aşağıdaki gibi yazılır (Hong ve ark., 2004):

$\left(m_{t u ̈ p, F D M} \cdot C_{p, t u ̈ p}+m_{F D M} \cdot C_{p, s i v l}\right)\left(T_{o}-T_{k}\right)=h A_{t u ̈ p} A_{1}$

$\left(m_{t u ̈ p, F D M} \cdot C_{p, t u ̈ p}+m_{F D M} \cdot \frac{C_{p, s i v l+k a t \imath}}{2}\right)\left(T_{e}-T_{d}\right)+m_{F D M} \cdot h_{e}=h A_{t u ̈ p} A_{2}$

$\left(m_{\text {tü }, F D M} \cdot C_{p, t u ̈ p}+m_{F D M} \cdot C_{p, k a t l}\right)\left(T_{d}-T_{s}\right)=h A_{t u ̈ p} A_{3}$

Burada, Eşitlik (2) sıvı fazı, Eşitlik (3) katı -sıvı faz geçişini ve Eşitlik (4) katı faz süreçlerini ifade etmektedir. Eşitlik (5-7) ise referans madde olarak kullanılan saf su için yazılmıştır (Hong ve ark., 2004):

$\left(m_{\text {tüp }, \text { su }} \cdot c_{p, t \text { tü }}+m_{s u} \cdot c_{p, s u}\right)\left(T_{o}-T_{k}\right)=h A_{\text {tüp }}^{\prime} A_{1}^{\prime}$

$\left(m_{t u ̈ p, s u} \cdot c_{p, t u ̈ p}+m_{s u} \cdot c_{p, s u}\right)\left(T_{e}-T_{d}\right)=h A_{t u ̈ p}^{\prime} A_{2}^{\prime}$

$\left(m_{t u ̈ p, s u} \cdot c_{p, t u ̈ p}+m_{s u} \cdot c_{p, s u}\right)\left(T_{d}-T_{s}\right)=h A_{\text {tü } p}^{\prime} A_{3}^{\prime}$

Bu eşitliklerde bulunan alanlar ise aşağıdaki gibi hesaplanabilir (Eşitlik (8-10)) (Hong ve ark., 2004):

$A_{1}=\int_{0}^{t_{1}}\left(T_{0}-T_{k}\right) d t$

$A_{2}=\int_{t_{1}}^{t_{2}}\left(T_{e}-T_{d}\right) d t$

$A_{3}=\int_{t_{2}}^{t_{3}}\left(T_{d}-T_{s}\right) d t$ 
Böylece, T-Kayıt Yöntemi ile yukarıda verilen eşitlikler kullanılarak, sıv1 faz özgül 1sıs1 $\left(c_{p, s i v \imath}\right)$, katı faz özgül 1sısı $\left(c_{p, k a t \imath}\right)$ ve kristallenme gizli ısısı $\left(h_{k}\right)$, sırasıyla, Eşitlik (11), Eşitlik (12) ve Eşitlik (13) vasıtasıyla bulunabilir(Hong ve ark., 2004):

$$
\begin{aligned}
& c_{p, s l v l}=\frac{m_{t u ̈ p, s u} \cdot c_{p, t u ̈ p}+m_{s u} \cdot c_{p, s u}}{m_{F D M}} \frac{A_{t u ̈ p}}{A_{\text {tü }}^{\prime}} \frac{A_{1}}{A_{1}^{\prime}}-\frac{m_{t u ̈ p, F D M}}{m_{F D M}} c_{p, t u ̈ p} \\
& c_{p, k a t l}=\frac{m_{t u ̈ p, s u} \cdot C_{p, t u ̈ p}+m_{s u} \cdot C_{p, s u}}{m_{F D M}} \frac{A_{t u ̈ p}}{A_{t u ̈ p}^{\prime}} \frac{A_{3}}{A_{3}^{\prime}}-\frac{m_{t u ̈ p, F D M}}{m_{F D M}} c_{p, t u ̈ p} \\
& h_{k}=-\left(\left(\frac{m_{t u ̈ p, F D M}}{m_{F D M}} c_{p, t u ̈ p}+\frac{c_{p, s i v l}+c_{p, k a t l}}{2}\right)\left(T_{e}-T_{d}\right)+\frac{m_{t u ̈ p, s u} \cdot c_{p, t u ̈ p}+m_{s u} \cdot c_{p, s u}}{m_{F D M}} \frac{A_{t u ̈ p}}{A_{t u ̈ p}^{\prime}} \frac{A_{2}}{A_{2}^{\prime}}\left(T_{e}-T_{d}\right)\right)
\end{aligned}
$$

\section{Araștırma Sonuçları ve Tartıșma}

\subsection{Mikrokapsüllenmiş FDM’nin Morfolojisi ve Partikül Boyut Dağılımı}

N-hekzadekanın St-DVB kabuk ile mikro boyutta kapsülenmesi ile beyaz renkte ve toz formunda ürün elde edilmiştir. Uygulama alanı için oldukça önemli bir kriter olan parçacık büyüklüğünün ve boyut dağılımının belirlenmesi amacıyla mikrokapsüllerin taramalı elektron mikroskobu ile elde edilen görüntüsü, boş kabuk malzeme St-DVB ile karşılaştırmalı olarak Şekil 3'de yer almaktadır. Şekil 3'den de görüldüğü üzere HD/St-DVB mikrokapsülleri oldukça pürüzsüz bir yüzeye sahip olmakla beraber küresele şekle yakın bir oluşum göstermiştir. Tanecikli yapının oluşumu mikrokapsüllerin oluştuğunu kanıtlamaktadır. Boş kabuk malzemeye kıyasla mikrokapsüllenmiş FDM'nin agregasyona daha eğilimli olduğu görülmekle beraber, görüntülerde n-hekzadekanın mikrokapsüllerin dışında kaldığına dair bir bulgu yer almamaktadır. Ayrıca elde edilen DSC sonuçları da mikrokapsüllerin FDM içeriklerinin nispeten yüksek olduğunu göstermiştir. Taramalı elektron mikroskobu görüntülerinden yapılan hesaplamalar sonucunda HD/St-DVB mikrokapsüllerinin ortalama partikül çapı $0,206 \pm 0,035 \mu \mathrm{m}$ bulunurken, partikül boyut dağılımının $0,14 \mu \mathrm{m}$ ile $0,30 \mu \mathrm{m}$ arasında oldukça düzgün ve dar bir dağılım sergilediği görülmüştür (Şekil 4). Partiküllerin 1,0 $\mu \mathrm{m}$ ’nin altında $(0,206 \mu \mathrm{m}<1 \mu \mathrm{m})$ bir boyuta sahip olması nedeniyle elde edilen kapsüllerin nano boyutta $(206 \pm 35 \mathrm{~nm})$ olduğu da ifade edilebilir.
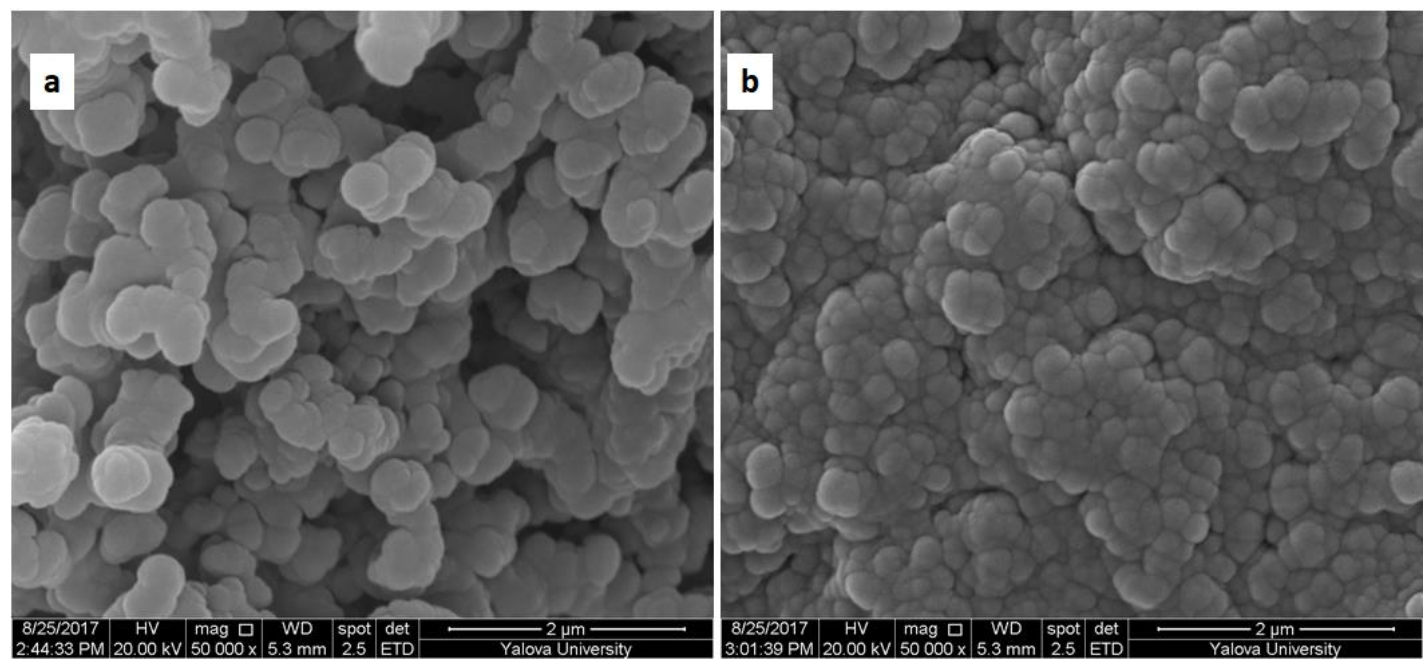

Şekil 3. (a) St-DVB boş kabuk malzemenin, (b) Mikrokapsüllenmiş FDM'nin (MikroFDM) taramall elektron mikroskobu görüntüleri 


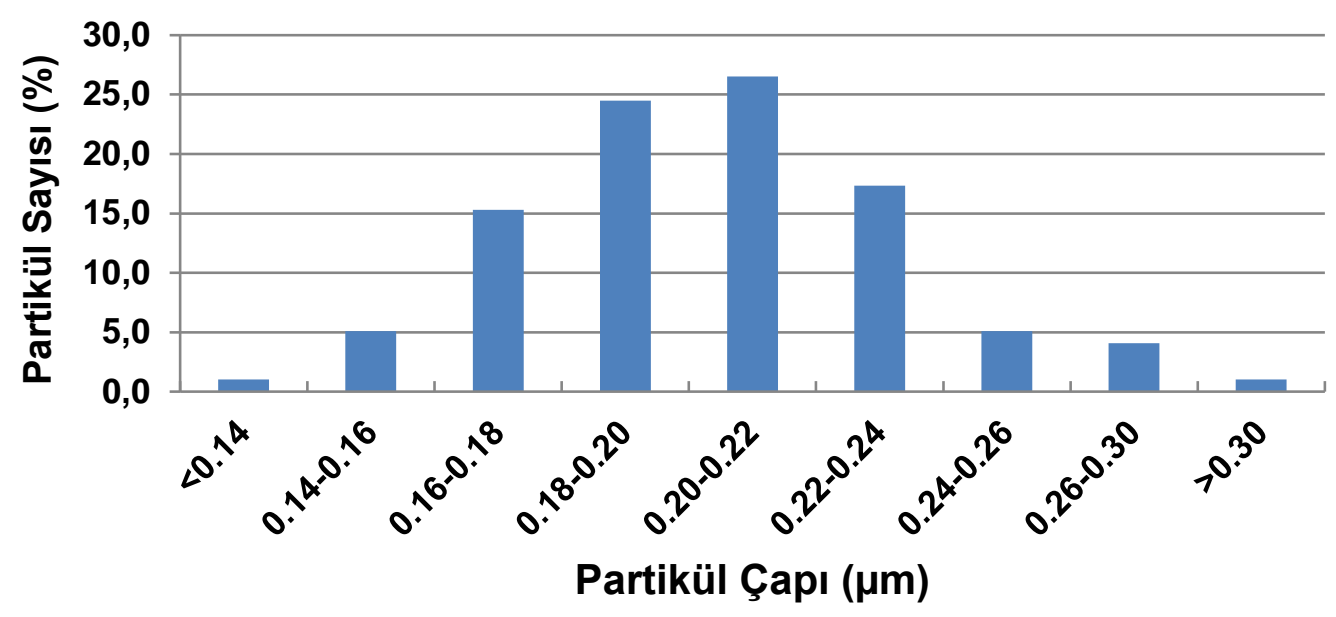

Şekil 4. Mikrokapsüllenmiş FDM’nin (MikroFDM) partikül boyut dă̆ılımı grafiği

\subsection{Mikrokapsüllenmiş FDM'nin Kimyasal Karakterizasyonu}

Mikrokapsüllenmiş FDM (MikroFDM), n-hekzadekan ve St-DVB boş kabuk malzemenin FT-IR spektroskopisi ile elde edilen FT-IR spektrumları Şekil 5'de yer almaktadır. Saf n-hekzadekan piki incelendiğinde 2956, 2921 ve $2852 \mathrm{~cm}^{-1}$ de görülen pikler alifatik C-H gerilme titreşimlerinden kaynaklanırken, $1466 \mathrm{~cm}^{-1}$ ve $1378 \mathrm{~cm}^{-1}$ de görülen pikler sırasıyla C-H bükülme titreşimi ve metil bükülme titreşiminden ileri gelmektedir. $720 \mathrm{~cm}^{-1}$ de ise uzun-zincir metil bükülme titreşimi yer almaktadır. Bunun yanında StDVB kopolimer kabuk malzemeye ait spektrum incelendiğinde polistirenin karakteristik pikleri olan aromatik $\mathrm{C}=\mathrm{C}$ ve $\mathrm{C}$ - $\mathrm{H}$ gerilmelerinin sırasıyla $1600-1450 \mathrm{~cm}^{-1}$ ve $750-700 \mathrm{~cm}^{-1}$ bandında olduğu görülmektedir. Çekirdek kısmında n-hekzadekan ve kabuk kısmında ise St-DVB içeren MikroFDM'e ait spektrum incelendiğinde ise hem n-hekzadekana hem de St-DVB kabuğa ait tüm karakteristik piklerin spektrumda yer alması n-hekzadekanın başarılı bir şekilde St-DVB kabuk ile kapsüle edildiğini doğrulamaktadır.

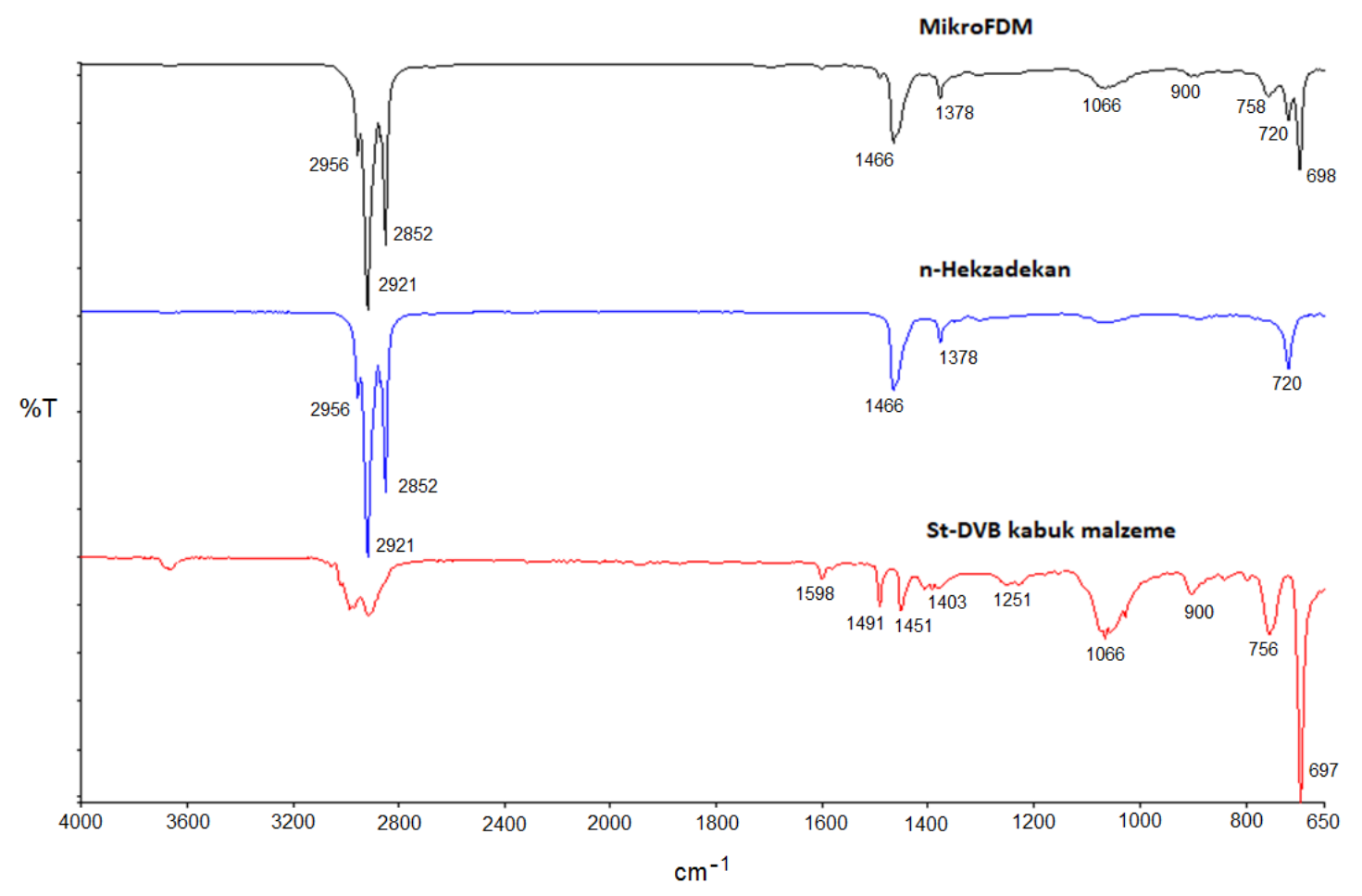

Şekil 5. Mikrokapsüllenmiş FDM'nin (MikroFDM), n-Hekzadekanın ve St-DVB kopolimer boş kabuk malzemenin FT-IR spektrumları 


\subsection{Mikrokapsüllenmiş FDM'lerin Isıl Özellikleri ve Gizli Isı Depolama Kapasiteleri}

St-DVB kopolimer boş kabuk malzemenin, n-Hekzadekanın ve mikrokapsüllenmiş FDM'nin (MikroFDM) DSC grafikleri Şekil 6'da verilmiştir. N-hekzadekanın ve MikroFDM'nin DSC eğrilerinden elde edilen ssıl veriler ise Tablo 2'de özetlenmiştir. Şekil 6 ve Tablo 2'den görüldüğ̈̈ üzere mikroPCM için erime ve kristallenme pik sıcaklıkları sırasıyla $23,54{ }^{\circ} \mathrm{C}$ ve $14,61{ }^{\circ} \mathrm{C}$ olarak bulunurken, n-hekzadekan için bu değerler sırasıyla $25,51^{\circ} \mathrm{C}$ ve $12,86^{\circ} \mathrm{C}$ olarak ölçülmüştür. Buna göre n-hekzadekan ile mikrokapsüllerin erime ve kristallenme sıcaklıkları arasında küçük bir fark bulunmaktadır. Bundan başka, örneklerin erime entalpileri karşılaştırıldığında nhekzadekanın erime ve kristallenme entalpileri sirasıyla 191,18 J.g ${ }^{-1}$ ve -192,56 J.g-1 iken, MikroFDM'nin erime entalpisinin 131,07

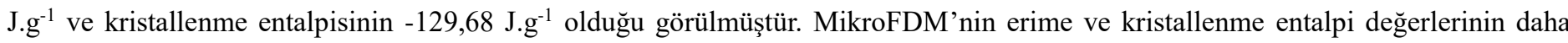
düşük bulunması polistiren kabuğun varlığının doğal bir sonucudur. Şekil 6a'da görüldüğü gibi St-DVB kopolimer kabuk FDM içermediğinden dolayı söz konusu sıcaklık aralığında DSC grafiğinde herhangi bir pik vermemiştir. FDM kapsülasyon işleminde elde edilen kapsüllerin yüksek FDM içeriğine sahip olmaları, o derece yüksek 1sıl depolama kapasitesine de sahip olacaklarının bir göstergesidir. Yüksek 1sı depolama kapasitesine sahip mikrokapsüllerin ise buna bağlı olarak uygulama alanının genişleyebileceği söylenebilir. Buna göre üretilen mikrokapsüllerin yüksek gizli 1sı depolama kapasitesine (131,07 J.g-1) sahip olduklar1 görülmektedir. Ayrıca elde edilen mikrokapsüllerin Eşitlik (1) kullanılarak hesaplanan ve Tablo 2'de verilen \%FDM içeriği (\%n-hekzadekan içeriği) $\% 68,55$ olarak bulunmuştur.

Tablo 2. N-Hekzadekan ve mikrokapsüllenmiş FDM’nin (MikroFDM) DSC ĕgrilerinden alınan ısıl özellikleri

\begin{tabular}{|c|c|c|c|c|c|c|c|c|c|}
\hline Malzeme & $\begin{array}{l}{ }^{\mathrm{a}} \mathbf{T}_{\text {ie }} \\
\left({ }^{\circ} \mathbf{C}\right)\end{array}$ & $\begin{array}{l}{ }^{\mathbf{b}} \mathbf{T}_{\mathbf{p e}} \\
\left({ }^{\circ} \mathbf{C}\right)\end{array}$ & $\begin{array}{l}{ }^{\mathbf{c}} \mathbf{T}_{\text {se }} \\
\left({ }^{\circ} \mathbf{C}\right)\end{array}$ & $\begin{array}{c}\mathrm{d} \Delta \mathrm{H}_{\mathrm{e}} \\
\left({\left.\mathrm{J} . \mathrm{g}^{-1}\right)}^{-1}\right.\end{array}$ & $\begin{array}{l}{ }^{\mathrm{e}} \mathbf{T}_{\mathrm{ik}} \\
\left({ }^{\circ} \mathrm{C}\right)\end{array}$ & $\begin{array}{l}{ }^{\mathbf{f}} \mathbf{T}_{\mathbf{p k}} \\
\left({ }^{\circ} \mathbf{C}\right)\end{array}$ & $\begin{array}{l}{ }^{\mathbf{g}} \mathbf{T}_{\text {sk }} \\
\left({ }^{\circ} \mathbf{C}\right)\end{array}$ & $\begin{array}{l}{ }^{\mathrm{h}} \Delta \mathbf{H}_{\mathrm{k}} \\
\left({\left.\mathrm{J} . \mathrm{g}^{-1}\right)}\right.\end{array}$ & $\begin{array}{c}\text { n-hekzadekan } \\
\text { içeriği (\%ağır.) }\end{array}$ \\
\hline N-hekzadekan & 20,22 & 25,51 & 33,00 & 191,18 & 16,04 & 12,86 & 8,00 & $-192,56$ & 100,0 \\
\hline MikroFDM & 18,47 & 23,54 & 34,00 & 131,07 & 16,51 & 14,61 & 0,00 & $-129,68$ & 68,55 \\
\hline
\end{tabular}

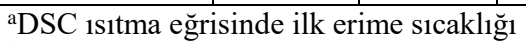

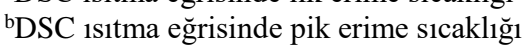

cDSC 1sıtma eğrisinde son erime sıcaklığ

${ }^{\mathrm{d} D S C}$ 1sitma eğrisinde erime entalpisi

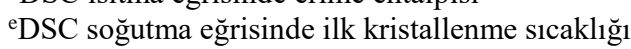

${ }^{\mathrm{f}}$ DSC soğutma eğrisinde pik kristallenme sicaklığ

'DSC soğutma eğrisinde son kristallenme sicaklığ

${ }^{\text {h} D S C ~ s o g ̆ u t m a ~ e g ̆ r i s i n d e ~ k r i s t a l l e n m e ~ e n t a l p i s i ~}$

Mikrokapsüllenmiş FDM'nin (MikroFDM), n-Hekzadekanın ve St-DVB kopolimer boş kabuk malzemenin termogravimetrik analiz (TGA) ile elde edilen ısıl bozunma eğrileri Şekil 7'de verilmiş ve bunlara ait sonuçlar Tablo 3'de özetlenmiştir. 


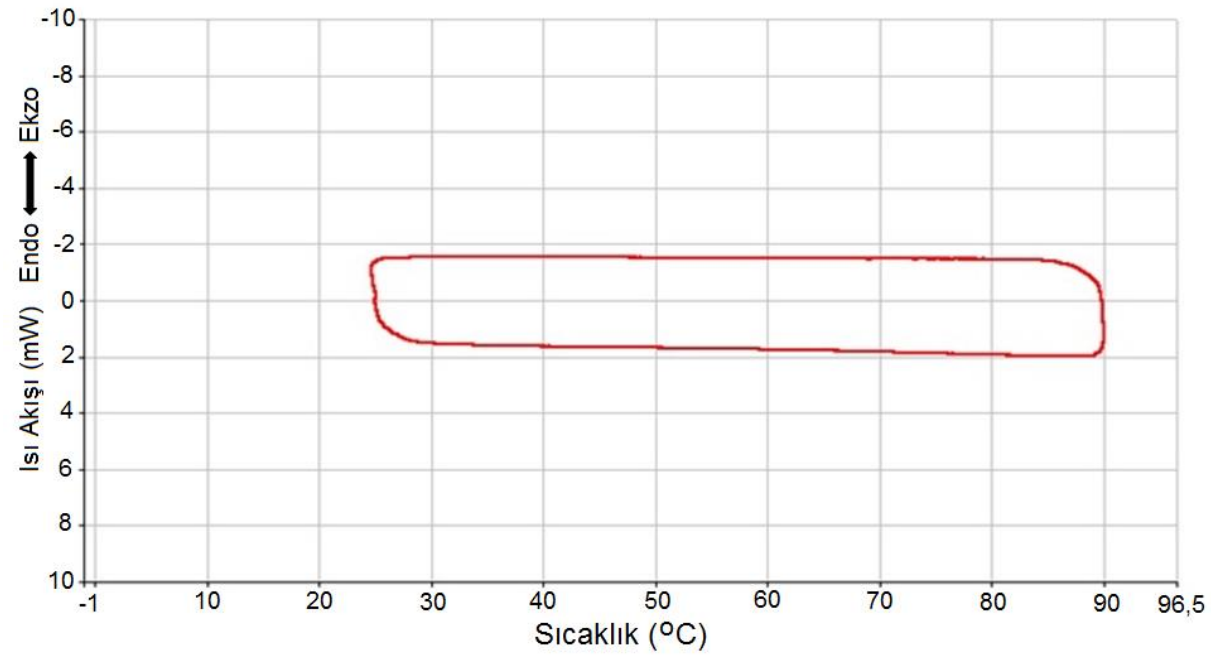

(a)

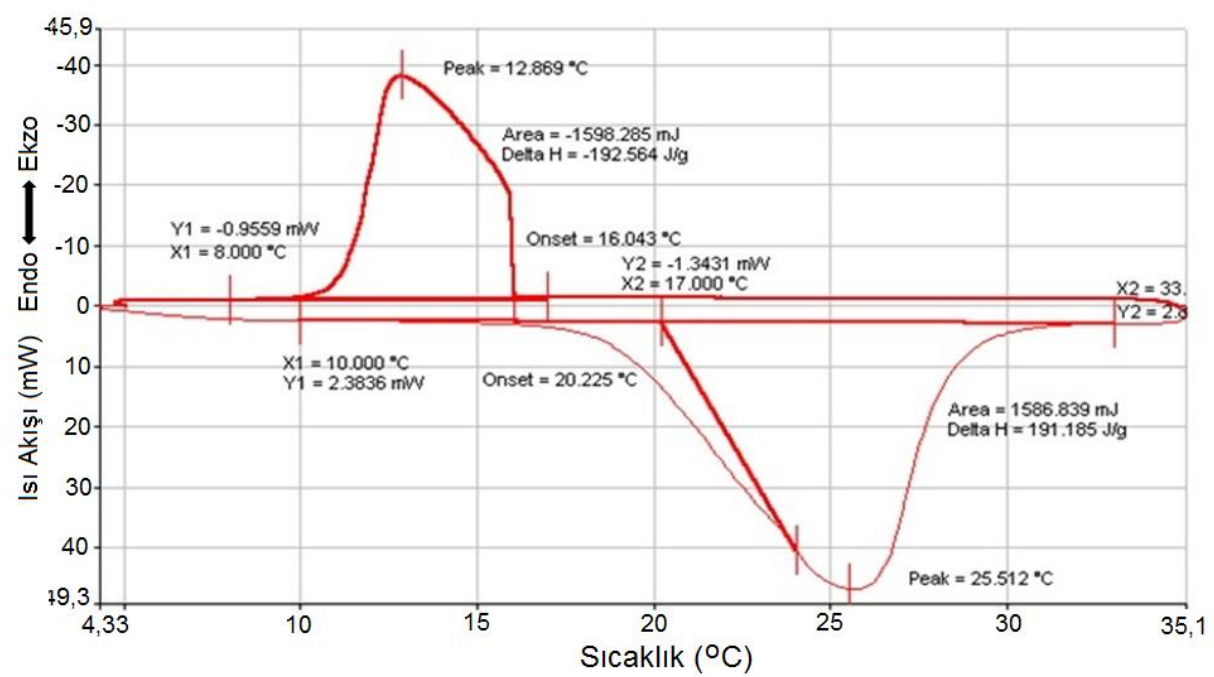

(b)

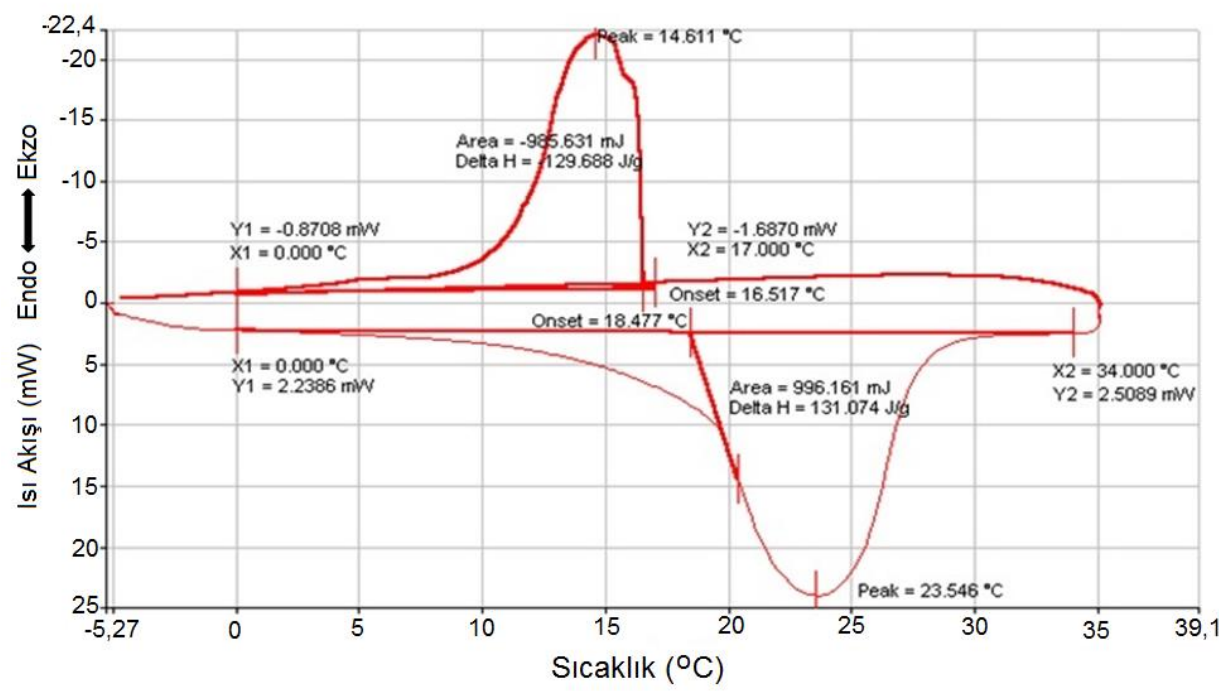

(c)

Şekil 6. (a) St-DVB kopolimer boş kabuk malzemenin, (b) n-Hekzadekanın ve (c)mikrokapsüllenmiş FDM'nin (MikroFDM) DSC eğrileri

Şekil 7 ve Tablo 3'den görüldüğü üzere boş St-DVB kabuk malzeme $382,5-450,8{ }^{\circ} \mathrm{C}$ sıcaklık aralı̆̆ında tek adımda bozunmakta ve bu sıcaklık aralığında ağırlığının \%96,2'sini kaybetmektedir. Benzer şekilde n-hekzadekan faz değişim maddesi de tek adımda 
bozunmakta ve $170,7-244,4^{\circ} \mathrm{C}$ sıcaklık aralığında ağırlığının \%99,6'sını kaybetmektedir. Bununla birlikte mikrokapsüllenmiş FDM'nin (MikroFDM) 1sıl bozunması iki adımda gerçekleşmiştir (Şekil 7). Mikrokapsüllerin ilk 1sıl bozunma adımı 122,2-232,2 ${ }^{\circ} \mathrm{C}$ sıcaklık aralığında meydana gelirken, ağırlık kaybı $\% 81,2$ olmuştur. Mikrokapsüllerin 384,7-450,6 ${ }^{\circ} \mathrm{C}$ sıcaklık aralığında gerçekleşen ikinci ısıl bozunma adımındaki \%18,5 ağırlık kaybı ise polistiren kabuk malzemenin bozunma adımı ile uyumludur. Bu sonuçlara göre ikinci ısıl bozunma adımındaki bozunma sıcaklıkları boş kabuk malzemeyle neredeyse aynıdır ve mikrokapsüllenmiş FDM'nin (MikroFDM) ve kabuk malzemenin benzer 1sıl kararlılığa sahip olduğu söylenebilir.

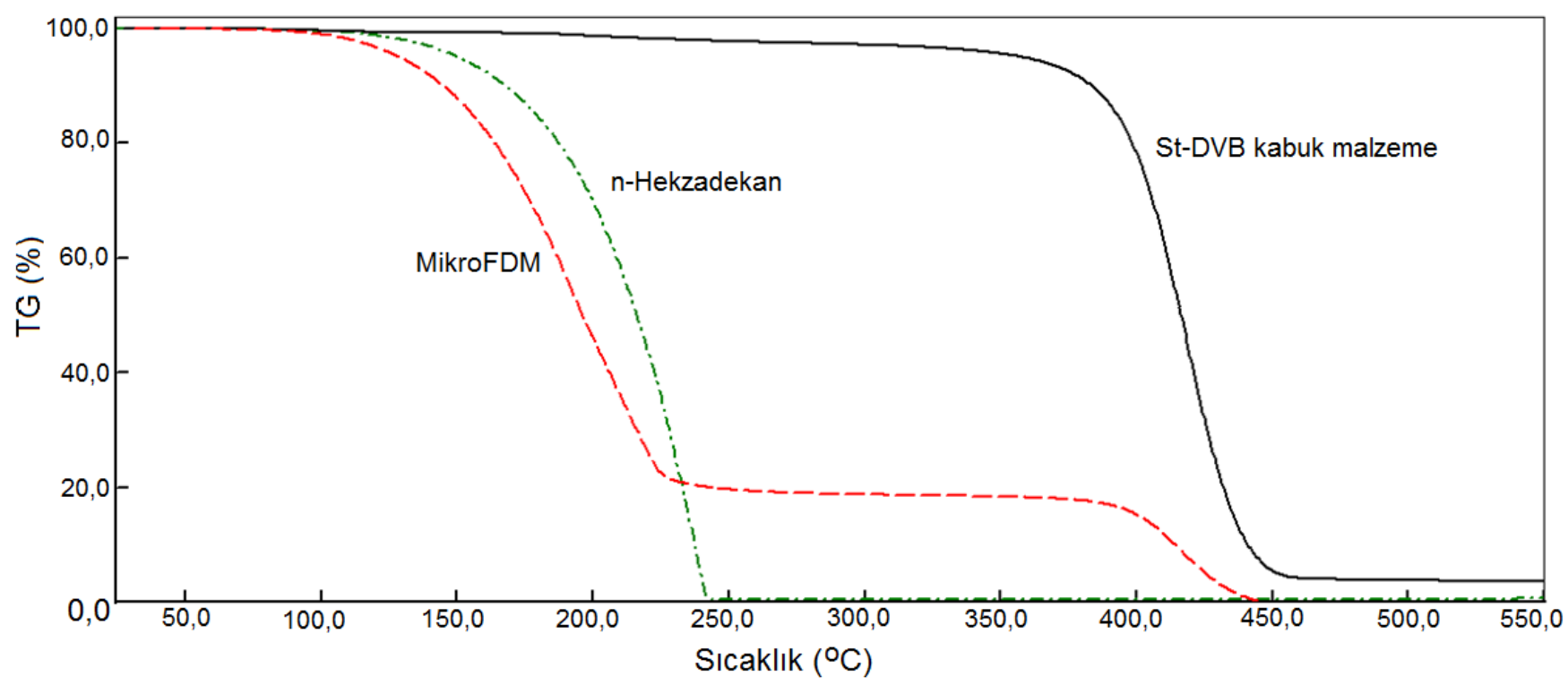

Şekil 7. Mikrokapsüllenmiş FDM'nin (MikroFDM), n-Hekzadekanin ve St-DVB kopolimer boş kabuk malzemenin termogravimetrik analiz (TGA) ile elde edilen ısl bozunma ĕgrileri

Tablo 3. Mikrokapsüllenmiş FDM'nin (MikroFDM), n-Hekzadekanin ve St-DVB kopolimer boş kabuk malzemenin TGA/DTG sonuçları

\begin{tabular}{|c|c|c|c|c|c|c|c|c|c|}
\hline $\begin{array}{c}\text { Örnek } \\
\text { No }\end{array}$ & Örnekler & $\begin{array}{c}\text { TGA bozunma } \\
\text { sıcaklık aralığı } \\
\text { 1.kademe } \\
\left({ }^{\circ} \mathrm{C}\right)\end{array}$ & $\begin{array}{c}\text { DTG pik } \\
\text { 1.kademe } \\
\left({ }^{\circ} \mathrm{C}\right)\end{array}$ & $\begin{array}{c}\text { Kütle } \\
\text { kaybı } \\
(\%)\end{array}$ & $\begin{array}{c}\text { Bozunma } \\
\text { hızı } \\
\left(\% . \text { dk }^{-1}\right) \\
\end{array}$ & $\begin{array}{c}\text { TGA bozunma } \\
\text { sicaklık aralığı } \\
2 . \text { kademe } \\
\left({ }^{\circ} \mathrm{C}\right) \\
\end{array}$ & $\begin{array}{c}\text { DTG pik } \\
\text { 2.kademe } \\
\left({ }^{\circ} \mathrm{C}\right)\end{array}$ & $\begin{array}{c}\text { Kütle } \\
\text { kaybı } \\
(\%)\end{array}$ & $\begin{array}{c}\text { Bozunma } \\
\text { hızI }^{-1} \\
\left(\% . \mathrm{dk}^{-1}\right)\end{array}$ \\
\hline 1 & St/DVB kopolimer kabuk & - & - & - & - & $382,5-450,8$ & 418,9 & 96,2 & 21,28 \\
\hline 2 & $\begin{array}{l}\text { Mikrokapsüllenmiş FDM } \\
\text { (MikroFDM) }\end{array}$ & $122,2-232,2$ & 191,4 & 81,2 & 11,84 & $384,7-450,6$ & 418,7 & 18,5 & 4,72 \\
\hline 3 & n-Hekzadekan & $170,7-244,4$ & 239,4 & 99,6 & 23,77 & - & - & - & - \\
\hline
\end{tabular}

\subsection{Isıl Özelliklerin T-Kayıt Yöntemi ile Belirlenmesi ve Test Edilmesi}

$\mathrm{Bu}$ çalışmada, n-hekzadekan/poli(stiren-ko-divinil benzen) mikrokapsüllerinin 1 sıl performansının incelenmesinde T-Kayıt yöntemi kullanılmıştır. Mikrokapsüllenmiş FDM'nin ve saf n-hekzadekanın 1sı depolama performansları Şekil 8'de görülen sıcaklık kontrollü sirkülasyonlu bir su banyosu ve veri kaydediciden (data logger) oluşan deneysel sistemde test edilmiştir. Bunun için, saf su (referans madde), saf n-hekzadekan ve mikroFDM deney tüpleri içerisine konularak sıcaklık kontrollü-sirkülasyonlu bir su banyosuna daldırılmıştır. Tüpler su banyosu kullanılarak ilk önce belirli bir sıcaklıktan numunelerin donma noktalarının altına soğutulmuş ve sonrasında erime noktalarının üzerindeki bir noktaya 1sıtılmıştır. Bu sayede, tüp içinde bulunan maddelerin sıcaklık ve faz değişimleri gözlemlenerek ısıl-çiftler (termokupullar) vasıtasıyla sıcaklığın zamanla değişimi veri kayıt cihazı ile kayıt edilmiştir. 


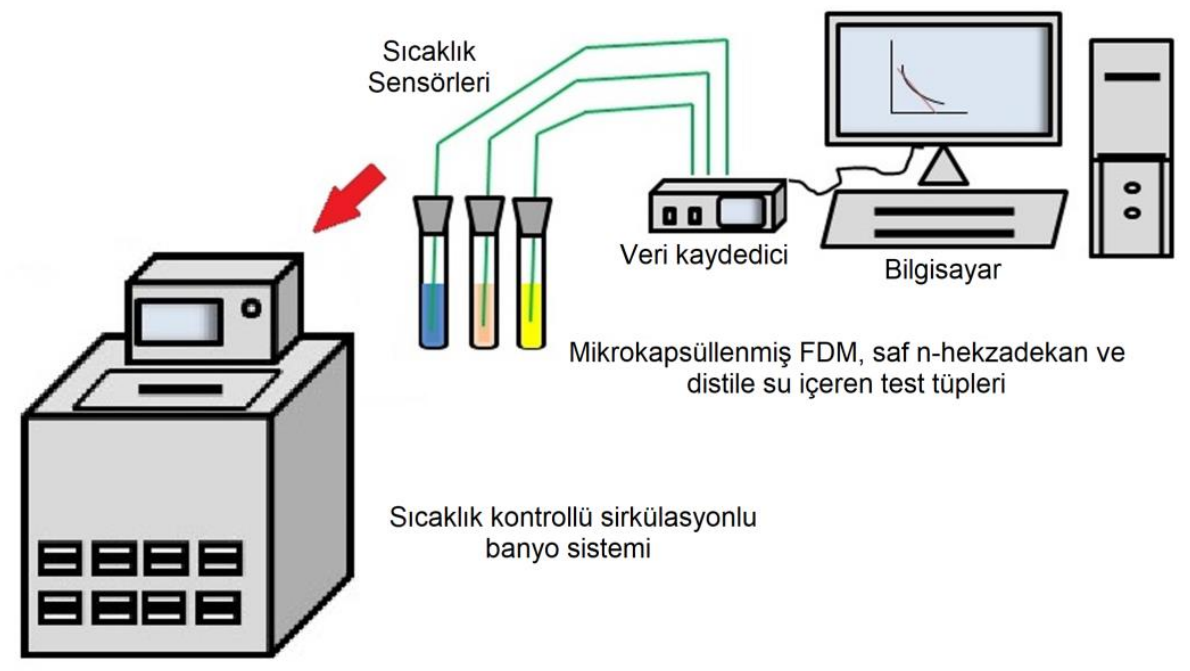

Şekil 8. Mikrokapsüllenmiş FDM'nin ve saf n-hekzadekanın ısll performanslarının değerlendirildiği deneysel test sistemi

Deneysel çalışma sırasında banyo içinde homojen sıcaklık dağılımının sağlanması için bir pompa vasıtasıyla banyo akışkanı sürekli devir daim ettirilmiştir. Aynı zamanda, numunelerin ve banyonun anlık sıcaklık değişimleri $\mathrm{K}$ tipi 1 sıl çiftler (termokupullar) kullanılarak ölçülmüş ve veri toplama sistemi ile kaydedilmiştir. Test için deney tüplerine eşdeğer miktarlarda tartılan numuneler konulmuştur. İlk olarak, FDM'lerin soğutma esnasındaki ısıl performansının belirlenmesi amacıyla soğutma prosesi incelenmiştir. Bunun için, banyo sıcaklığı $70^{\circ} \mathrm{C}$ civarına getirilmiş ve 1 sıl dengenin sağlanması beklenilmiştir. Bundan sonra, banyo hızla $4^{\circ} \mathrm{C}$ civarına soğutulmuştur. Böylece, soğutma prosesi boyunca saf-HD, mikro-FDM, saf su ve su banyosu sıcaklıklarının zamanla değişimi elde edilmiştir. Soğutma prosesindeki numunelerin sıcaklık değişimleri Şekil 9'da gösterilmiştir. Şekil 9 incelendiğinde, soğutma prosesi esnasında saf-HD ve mikro-FDM'e ait faz değişim sıcaklıklarının DSC analizi ile elde edilen değerler (Şekil 6b ve Şekil 6c) ile uyumlu olduğu görülmektedir. Bunun yanı sıra, soğutma esnasındaki faz değişim süreleri tespit edilmiştir. İkinci olarak, saf-HD ve mikro-FDM'nin ısıtma esnasındaki 1sıl performanslarını belirlemek üzere 1sıtma prosesi çalışılmıştır. Bunun için, su banyosunun $4^{\circ} \mathrm{C}$ civarında isıl dengeye gelmesi beklenilmiştir. Sonrasında ise banyo $70^{\circ} \mathrm{C}$ civarına 1 sıtılmıştır. Böylece, ssıtma prosesi boyunca saf-HD, mikro-FDM, saf su ve su banyosu sıcaklıklarının zamanla değişimi elde edilmiştir. Isıtma prosesinde, numunelere ait anlık sıcaklık değişimleri Şekil 10'da gösterilmiştir. Şekil 10 incelendiğinde, 1sıtma prosesi esnasında saf-HD ve mikro-FDM ait faz değişim sıcaklıklarının DSC analizi ile elde edilen değerleri (Şekil 6b ve Şekil 6c) teyit ettiği görülmüştür. Bununla beraber, 1sıtma prosesi için faz değişim süreleri gözlemlenmiştir.

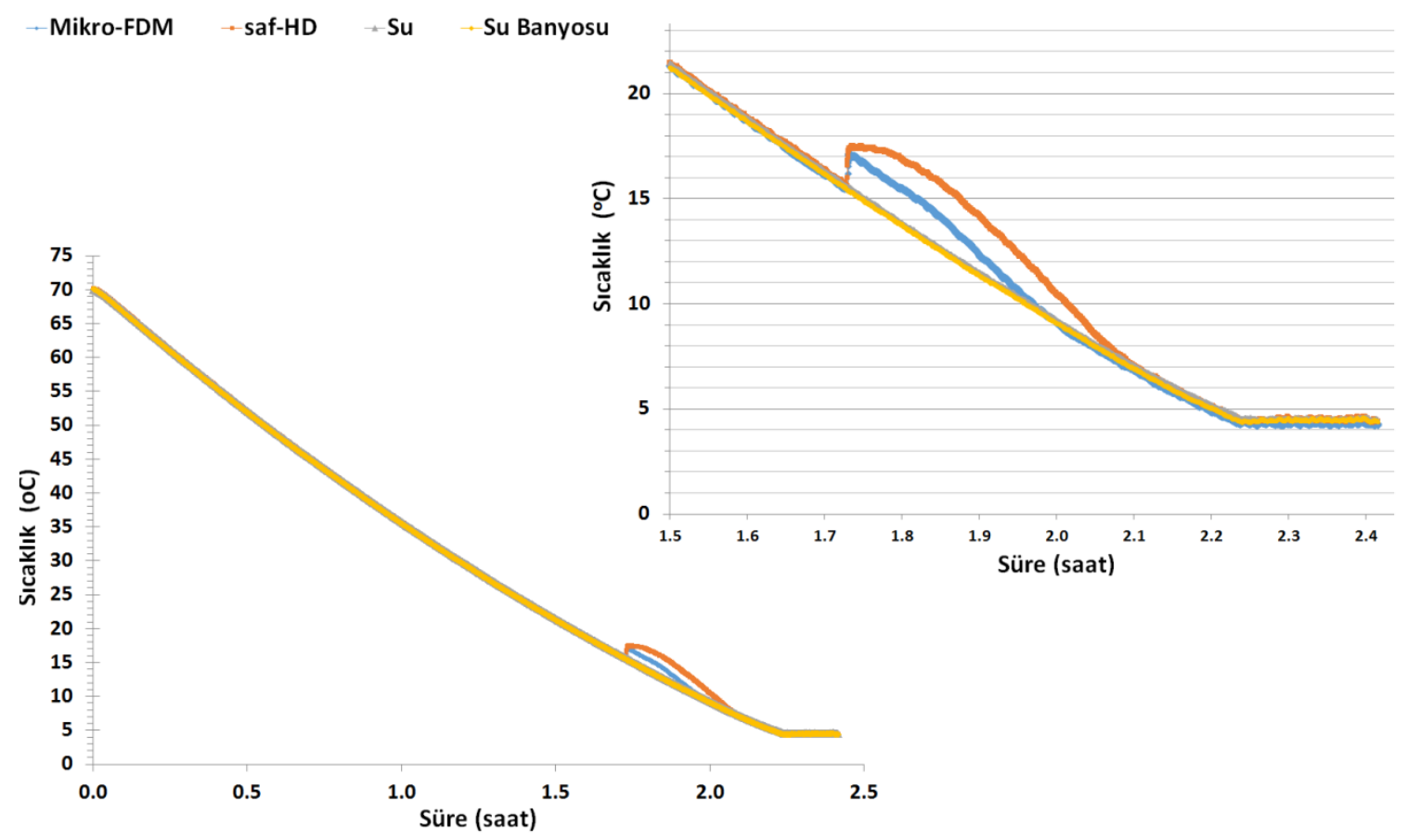

Şekil 9. Soğutma prosesi boyunca Saf-HD, mikro-FDM, Saf Su ve Su Banyosu sıcaklıklarının zamanla değişimi 

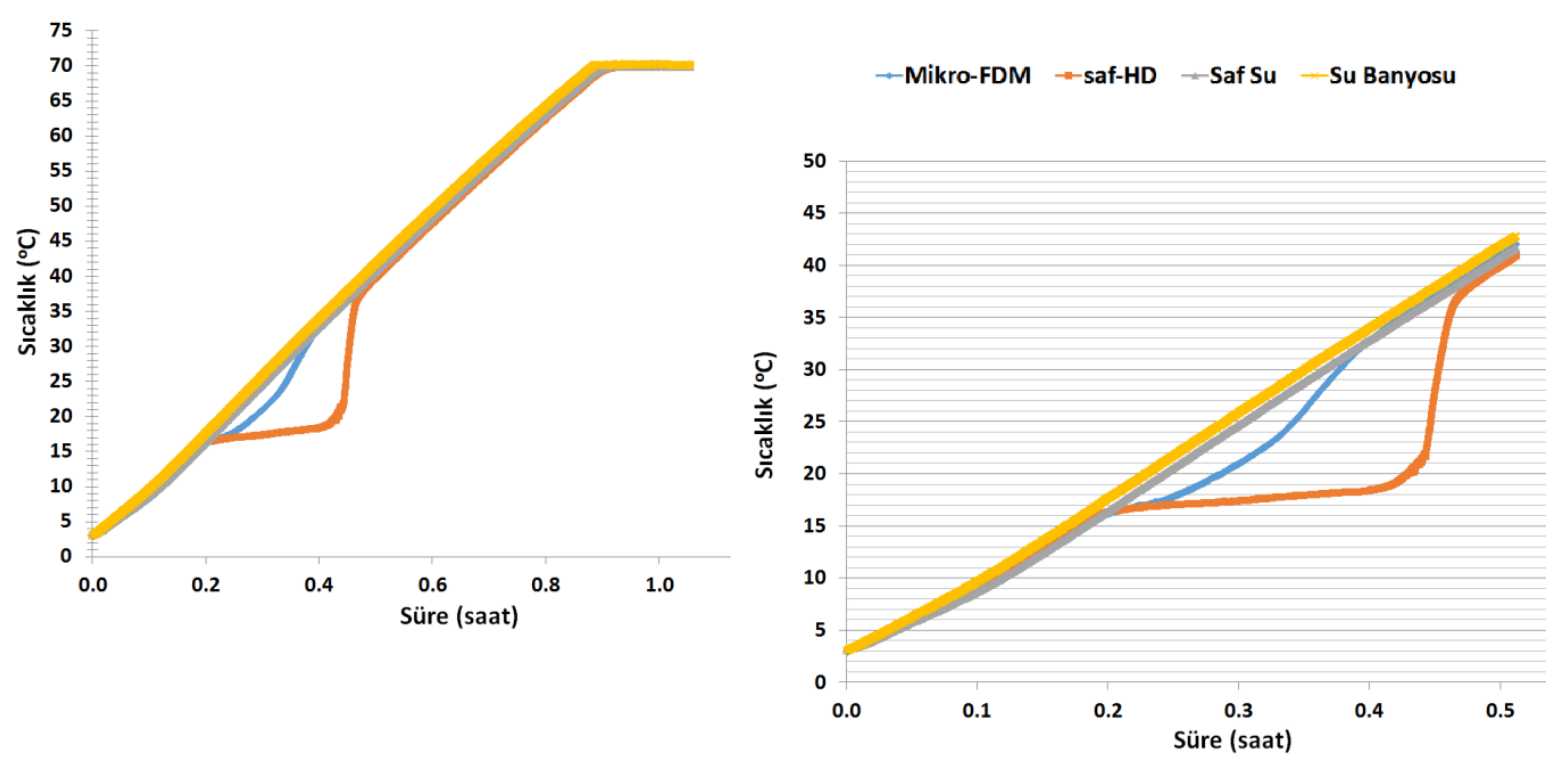

Şekil 10. Isıtma prosesi boyunca Saf-HD, mikro-FDM, Saf Su ve Su Banyosu sıcakliklarının zamanla değişimi

Bu çalışmada, T-kayıt yöntemi kullanılarak soğutma prosesi verileri kullanılarak elde edilen soğutma eğrilerinin altında kalan alanlar yardımıyla ve Eşitlik (2-13) kullanılarak mikrokapsüllenmiş faz değişim maddesi için (MikroFDM) kristallenme gizli 1Sı değeri hesaplanmıştır. Tablo 4'te T-kayıt yöntemi kullanılarak MikroFDM için elde edilen bulgular DSC analizi ile belirlenen bulgular ile karşılaştırmalı olarak gösterilmektedir. Görüldügüü üzere T-kayıt yöntemiyle elde edilen sonuçlar, DSC verileri ile uyumludur.

Tablo 4. MikroFDM için DSC analizi ve T-kayıt yöntemi ile belirlenen ısl özelliklerin karşılaştırllması

\begin{tabular}{|c|c|c|c|c|}
\hline Malzeme & $\begin{array}{l}{ }^{\mathrm{a}} \mathbf{T}_{\mathrm{ik}} \\
\left({ }^{\circ} \mathrm{C}\right)\end{array}$ & $\begin{array}{l}{ }^{\mathrm{b}} \mathbf{T}_{\mathrm{pk}} \\
\left({ }^{\circ} \mathbf{C}\right)\end{array}$ & $\begin{array}{l}{ }^{\mathrm{c}} \mathbf{T}_{\text {sk }} \\
\left({ }^{\circ} \mathbf{C}\right)\end{array}$ & $\begin{array}{l}{ }^{\mathrm{d}} \Delta \mathbf{H}_{\mathrm{k}} \\
\left(\mathrm{J} . \mathrm{g}^{-1}\right)\end{array}$ \\
\hline $\begin{array}{l}\text { MikroFDM } \\
\text { (DSC analizi: Deneysel Yöntem) }\end{array}$ & 16,51 & 14,61 & 0,00 & 129,68 \\
\hline $\begin{array}{l}\text { MikroFDM } \\
\text { (T-Kayı̈ Yöntemi: Deneysel + Sayısal yöntem) }\end{array}$ & 15,50 & 14,00 & 6,80 & 122,48 \\
\hline
\end{tabular}

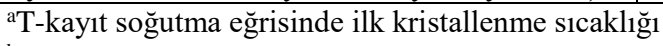

${ }^{\text {b} T-k a y ı t ~ s o g ̆ u t m a ~ e g ̆ r i s i n d e ~ p i k ~ k r i s t a l l e n m e ~ s ı c a k l ı g ̆ ~}$

${ }^{\mathrm{c}}$ T-kayıt soğutma eğrisinde son kristallenme sıcaklığ

dT-kayıt soğutma eğrisinde kristallenme entalpisi

\section{Sonuçlar}

Bu çalışmada, faz değişim maddesi olarak n-hekzadekan, binalarda yalıtım amaçlı sıklıkla kullanılan St-DVB kopolimer kabuk ile mikro boyutta faz inversiyon emülsifikasyonu yöntemiyle kapsülenmiştir. Elde edilen kapsüllerin \%FDM içeriği (\%n-hekzadekan içeriği) DSC analiz sonuçlarından yararlanılarak yapılan hesaplama sonucu \%68,55 olarak bulunmuş, FT-IR analiz sonucu ise kapsülleme işleminin başarıyla gerçekleştirildiğini ortaya koymuştur. Mikrokapsüllenmiş FDM'nin (MikroFDM) Taramalı Elektron Mikroskobunda gerçekleştirilen analizleri, mikrokapsüllenmiş FDM'nin (MikroFDM) hemen hemen küresel formda meydana geldiğini ve ortalama partikül çapının $0,206 \pm 0,035 \mu \mathrm{m}$ olduğunu göstermiştir. Kapsüllerin boyutunun $1,0 \mu \mathrm{m}$ 'nin altında olması nedeniyle nano boyutta elde edildikleri söylenebilir. Ayrıca, FDM kapsüllerin boyutları $0,14 \mu \mathrm{m}$ ile $0,30 \mu \mathrm{m}$ arasında değişen dar ve homojen bir dağılım sergilediği görülmüştür. TGA sonuçları, mikrokapsüllenmiş FDM'nin (MikroFDM) yüksek ısıl kararlılığa sahip olduğunu ortaya koymuştur. DSC analiz sonuçları ise St-DVB ile kapsüle edilmiş n-hekzadekanın sahip olduğu faz değişim sıcaklık aralığ $1\left(14,61-23,54^{\circ} \mathrm{C}\right)$ ve erime entalpisi $(131,074 \mathrm{~J} / \mathrm{g})$ ile düşük sicaklıklı 1sıl enerji depolama uygulamaları için potansiyel bir aday olduğunu göstermiştir. Bu verilere göre, üretilen mikrokapsüller ve saf n-hekzadekanın 1sıl performansı laboratuvar ölçekli bir sıcaklık kontrollü sirkülasyonlu bir banyo sisteminde test edilmiştir. Sonuçlar incelendiğinde, DSC analizinden bulunan entalpi değeri (129,68 $\mathrm{J} / \mathrm{g}$ ) ile T-Kayıt (deneysel + sayısal yöntem) ile bulunan entalpi değeri birbirine oldukça yakındır ve bu çalışma için yaklaşık \%5,5'lik bir farkla 122,48 J/g olarak bulunmuştur. Elde edilen sonuçlar temelinde, hazırlanan mikrokapsüllerin görece yüksek 1 sıl enerji depolama kapasitesine sahip oldukları bulunmuştur. Bunun yanı sıra, T-Kayıt yöntemi ile yapılan uygulamada erime ve katılaşma sıcaklıklarının DSC analizi ile uyumlu olduğu teyit edilmiştir. Sonuç olarak, elde edilen mikrokapsüllerin sahip olduğu 1sıl enerji depolama kapasiteleri, faz değişim sıcaklık aralığı, boyutları ve kabuk malzemenin uyumu dikkate alındığında binalarda yalıtım amaçlı iç mekan ısı konforunun sağlanması ve enerji tüketiminin azaltılması konusunda fayda sağlayabileceği ve yapı malzemesine entegre edilerek kullanımının uygun olabileceği değerlendirilmektedir. 


\section{Teşekkür}

Bu çalışmanın DSC analizlerinin gerçekleştirilmesindeki yardımlarından ötürü Dr. Ali Karaipekli'ye (Çankırı Karatekin Üniversitesi) teşekkür ederiz.

\section{Simge Listesi}

\begin{tabular}{|c|c|}
\hline $\mathbf{A}$ & : Alan $\left(\mathrm{br}^{2}\right)$ \\
\hline AIBN & : 2,2'-azobisizobütironitril \\
\hline$c_{p, k a t l}$ & : katı faz özgül 1sısı $\left(\mathrm{kJ} / \mathrm{kg} .{ }^{\circ} \mathrm{C}\right)$ \\
\hline$c_{p, s l v l}$ & : sıv1 faz özgül 1sısı $\left(\mathrm{kJ} / \mathrm{kg} .{ }^{\circ} \mathrm{C}\right)$ \\
\hline CTAB & : Setil Trimetil Amonyum Bromür \\
\hline DSC & : Diferansiyel Taramalı Kalorimetre \\
\hline DTG & : Diferansiyel Termogravimetrik Analiz \\
\hline DVB & : Divinilbenzen \\
\hline FDM & : Faz Değişimim Maddesi \\
\hline FT-IR & : Fourier Dönüşümlü Kızıl Ötesi Spektrometresi \\
\hline HD & : n-hekzadekan \\
\hline $\mathbf{h}$ & : Konveksiyon 1sı transfer katsayısı $\left(\mathrm{W} / \mathrm{m}^{2} \mathrm{~K}\right)$ \\
\hline $\mathbf{h}_{\mathbf{e}}$ & : erime gizli 1sısı $(\mathrm{kJ} / \mathrm{kg})$ \\
\hline $\mathbf{h}_{\mathbf{k}}$ & : kristallenme gizli 1s1S1 $(\mathrm{kJ} / \mathrm{kg})$ \\
\hline$m$ & : Madde miktarı (g) \\
\hline MikroFDM & : Mikrokapsüllenmiş Faz Değiş̧im Maddesi \\
\hline SEM & : Taramalı Elektron Mikroskobu \\
\hline St & : Stiren \\
\hline TGA & : Termogravimetrik Analiz \\
\hline $\mathbf{t}$ & : Zaman (Saniye) \\
\hline $\mathrm{T}$ & : Sicaklık $\left({ }^{\circ} \mathrm{C}\right)$ \\
\hline$\Delta \mathrm{H}$ & : Entalpi Değişimimi \\
\hline
\end{tabular}

$\begin{array}{ll}\text { Alt Simgeler } & \\ \text { d } & \text { :donma } \\ \text { e } & \text { :erime } \\ \mathbf{i} & : \text { ilk } \\ \mathbf{k} & : \text { kristallenme } \\ \mathbf{o} & : \text { referans } \\ \mathbf{s} & : \text { son } \\ \text { ie } & : \text { ilk erime } \\ \text { pe } & : \text { pik erime } \\ \text { se } & : \text { son erime } \\ \text { ik } & : \text { ilk kristallenme } \\ \text { pk } & : \text { ik kristallenme } \\ \text { sk } & : \text { son kristallenme }\end{array}$

\section{Kaynakça}

Alay, S. Göde, F., Alkan, C. (2009). Isıl Enerji Depolama İçin Poli(etil akrilat)/Hekzadekan Mikrokapsüllerinin Üretilmesi ve Karakterizasyonu. Tekstil Teknolojileri Elektronik Dergisi, Cilt: 3, No: 3, 33-46.

Bo, H., Gustafsson, E.M., Setterwall, F. (1999). Tetradecane and hexadecane binary mixtures as phase change materials (PCMs) for cool storage in district cooling systems. Energy, 24, 1015-1028.

Bo, H., Martin, V., Setterwall, F. (2003). Liquid-solid phase equilibrium study of tetradecane and hexadecane binary mixtures as phase change materials (PCMs) for comfort cooling storage. Fluid Phase Equilibria, 212, 97-109.

Fang, G., Li, H., Chen, Z., Liu, X. (2010). Preparation and characterization of flame retardant n-hexadecane/silicon dioxide composites as thermal energy storage materials. Journal of Hazardous Materials, 181,1004-1009.

Gao, G.B., Qian, C.X., Gao, M.J. (2010). Preparation and characterization of hexadecane microcapsule with polyurea-melamine formaldehyde resin shell materials. Chinese Chemical Letters, 21,533-537.

Gondora, W., Doudin, K., Nowakowski, D.J., Xiao, B., Ding, Y., Bridgwater, T., Yuan, Q. (2016). Encapsulation of phase change materials using rice-husk-char. Applied Energy, 182, 274-281. 
Hong, H., Kim, S.K., Kim, Y-S. (2004). Accuracy improvement of T-history method for measuring heat of fusion of various materials, International Journal of Refrigeration, 27, 360-366.

Jeon, J., Jeong, S.G., Lee, J-H., Seo, J., Kim, S. (2012). High thermal performance composite PCMs loading xGnP for application to building using radiant floor heating system. Solar Energy Materials \& Solar Cells, 101, 51-56.

Karaipekli, A., Sarı, A. (2016). Development and thermal performance of pumice/organicPCM/gypsum composite plasters for thermal energy storage in buildings, Solar Energy Materials \& Solar Cells, 149, 19-28.

Kim, S., Chang, S.J., Chung, O., Jeong, S-G., Kim, S. (2014). Thermal characteristics of mortar containing hexadecane/xGnPSSPCM and energy storage behaviors of envelopes integrated with enhanced heat storage composites for energy efficient buildings. Energy and Buildings, 70, 472-479.

Lashgari, S., Arabi, H., Mahdavian, A.R., Ambrogi, V. (2017). Thermal and morphological studies on novel PCM microcapsules containing n-hexadecane as the core in a flexible shell. Applied Energy, 190,612-622.

Mert M.S., Sert M., Mert H.H. (2018). Isıl Enerji Depolama Sistemleri İçin Organik Faz Değiştiren Maddelerin Mevcut Durumu Üzerine Bir İnceleme. Mühendislik Bilimleri ve Tasarım Dergisi, 6(1), 161-174.

Mert H.H., Mert M.S. (2019a). Preparation and characterization of encapsulated phase change materials in presence of gamma alumina for thermal energy storage applications. Thermochimica Acta, 681,178382.

Mert M.S., Mert H.H., Sert, M. (2019b). Microencapsulated Oleic-Capric Acid/Hexadecane Mixture as Phase Change Material for Thermal Energy Storage. Journal of Thermal Analysis and Calorimetry, 136, 1551-1561.

Peck, J.H., Kim, J-J., Kang, C., Hong, H. (2006). A study of accurate latent heat measurement for a PCM with a low melting temperature using T-history method. International Journal of Refrigeration, 29,1225-1232.

Sarı, A., Karaipekli, A. (2012). Fatty acid esters-based composite phase change materials for thermal energystorage in buildings, Applied Thermal Engineering, 37, 208-216.

Sarier, N. Onder, E. (2007). Thermal characteristics of polyurethane foams incorporated with phase change materials. Thermochimica Acta, 454, 90-98.

Sarier, N., Onder, E., Ukuser, G. (2015). Silver incorporated microencapsulation of n-hexadecane and n-octadecane appropriate for dynamic thermal management in textiles. Thermochimica Acta, 613, 17-27.

Velez, C., Khayet, M., Zárate, J.M.O. (2015). Temperature-dependent thermal properties of solid/liquid phase change even-numbered n-alkanes: n-Hexadecane, n-octadecane and n-eicosane. Applied Energy, 143, 383-394.

Yinping, Z., Yi, J., Yi, J. (1999). A simple method, the T -history method, of determining the heat of fusion, specific heat and thermal conductivity of phase-change materials. Measurement Science and Technology, 10, 201-205. 